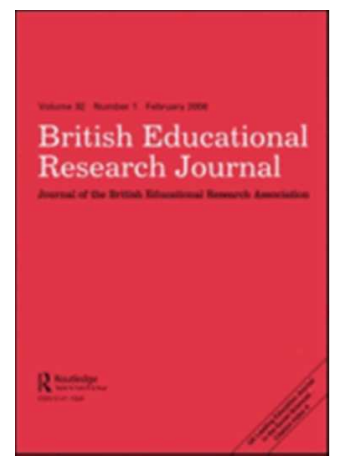

\title{
Challenging the Orthodoxy on Pupil Gang Involvement: When Two Social Fields Collide
}

\begin{tabular}{|c|l|}
\hline Journal: & British Educational Research Journal \\
\hline Manuscript ID & CBER-2017-0085.R1 \\
\hline Manuscript Type: & Original Paper \\
\hline Keywords: & $\begin{array}{l}\text { All School Sectors < Formal Learning Contexts, Gangs, Violence, Social } \\
\text { field theories }\end{array}$ \\
& $\begin{array}{l}\text { Based on fieldwork conducted in five alternative provision schools across } \\
\text { three large cities in England, this paper explores the relationship between } \\
\text { young people's involvement in urban street gangs and their attitudes and } \\
\text { behaviour in school. By applying and developing a lens of social field } \\
\text { theory, the paper highlights the ways in which gang-involved young people } \\
\text { navigate their way between two distinct social fields, namely, that of the } \\
\text { street gang and that of the school. Although pupil gang involvement can } \\
\text { raise significant issues for schools, particularly around violence and } \\
\text { educational engagement, our findings challenge the prevailing orthodoxy } \\
\text { that depicts an entirely negative portrait of the effects of gang involvement } \\
\text { on pupils' attitudes and behaviour. Instead, through an analysis of } \\
\text { interview and observational data, we argue that there is nothing inevitable } \\
\text { about the internal logic of a gang social field permeating a school's gates. } \\
\text { Young people involved in gangs do not typically spend their entire waking } \\
\text { hours wedded to a 'gang member' identity - if they are given the } \\
\text { opportunity to transition away from the gang social field when they enter } \\
\text { the school gates, they will often embrace it. In short, the links between } \\
\text { pupils' involvement in gangs, violent behaviour in school and engagement } \\
\text { in education are more contingent and nuanced than is suggested by the } \\
\text { literature on gangs and schools to-date. }\end{array}$ \\
\hline
\end{tabular}




\title{
CHALLENGING THE ORTHODOXY ON PUPIL GANG INVOLVEMENT: WHEN TWO SOCIAL FIELDS COLLIDE
}

\begin{abstract}
Based on fieldwork conducted in five alternative provision schools across three large cities in England, this paper explores the relationship between young people's involvement in urban street gangs and their attitudes and behaviour in school. By applying and developing a lens of social field theory, the paper highlights the ways in which gang-involved young people navigate their way between two distinct social fields, namely, that of the street gang and that of the school. Although pupil gang involvement can raise significant issues for schools, particularly around violence and educational engagement, our findings challenge the prevailing orthodoxy that depicts an entirely negative portrait of the effects of gang involvement on pupils' attitudes and behaviour. Instead, through an analysis of interview and observational data, we argue that there is nothing inevitable about the internal logic of a gang social field permeating a school's gates. Young people involved in gangs do not typically spend their entire waking hours wedded to a 'gang member' identity - if they are given the opportunity to transition away from the gang social field when they enter the school gates, they will often embrace it. In short, the links between pupils' involvement in gangs, violent behaviour in school and engagement in education are more contingent and nuanced than is suggested by the literature on gangs and schools to-date.
\end{abstract}

Key words: All school sectors; Gangs; Violence; Social field theories

\section{Introduction}

Young people's life trajectories can be significantly affected by gang involvement. An established body of research indicates that gang-involved young people have an increased propensity to become both offenders and victims of crime, experience breakdowns in their familial and personal relationships, and engage in illicit substance use (Krohn et al. 2011; Melde and Esbensen 2011; Ozer and Engel 2012; Thornberry et al. 2003; Weerman et al. 2015). The issue of youth gangs was pushed up the UK political agenda by the 2011 riots and the contentious debates that followed regarding the role played by school-aged young people involved in gangs (Home Office 2016; Ministry of Justice 2011; Smithson and Ralphs 2016). Recent police data indicate that the problems associated with youth gangs have been growing since the riots, with the number of gang-related violent offences increasing by 55 percent between 2013 and 2015, and over one in five knife crimes with serious injury in 2015 being gang-related (MOPAC 2016).

Given that people are most likely to become involved in gangs during their early adolescent years, this can also pose serious challenges for schools (Craig et al. 2002; Lenzi et al. 2014; Sharkey et al. 2011). Furthermore, the role of schools in supporting young people involved in gangs is pressing because of the links between gang desistance and factors such as educational qualifications and employment (Gormally 2015; Pyrooz and Decker 2011). Despite its importance, however, there is a paucity of research on pupil gang involvement in the UK, which both limits our understanding and hinders the development of effective policy and practice responses that address the challenges being raised. Although now somewhat dated, a study commissioned by the National Association of Schoolmasters Union of Women Teachers did shed some light on issues around gangs and schools 
Challenging the orthodoxy on pupil gang involvement: When two social fields collide

(Broadhurst et al. 2009). Based on case studies in four UK schools, the research found that pupil gang involvement raised a number of problems, including the inculcation of anti-education attitudes, a decline in pupil and staff perceptions of safety, and a reduction in pupils' attendance rates. Findings from studies conducted outside the UK, most notably the USA, indicate that young people's involvement in gangs is linked to academic failure, school disengagement, low educational aspirations, educational frustration, high levels of anti-social behaviour in school, low test scores, an increase in violent victimisation, and unsafe school environments (Ang et al. 2015; Forber-Pratt et al. 2014; Hawkins et al. 2000; Higginson et al. 2014).

In short, research both within the UK and abroad has provided a consistently negative portrayal of the effects of gang involvement on pupils' attitudes and behaviour. By analysing qualitative data through a lens of social field theory, this paper indicates that the influence of gang involvement on pupils' attitudes and behaviour is more contingent and nuanced than the straightforwardly negative picture presented by previous studies.

The paper begins by outlining a social field theoretical framework, which we used to explore and interpret the data generated by fieldwork in five Alternative Provision schools in the UK. This is followed by a discussion of the study's methodology, including a brief description of Alternative Provision and information about the research sample and data analysis. The substantive findings of the paper are structured thematically, focusing firstly on the relationship between pupil gang involvement and violence, and secondly on gang-involved young people's engagement in education. The discussion and concluding sections of the paper highlight the paper's main findings and their potential implications for schools whose cohorts include pupils involved in gangs.

\section{Social field theory, the street casino and street capital}

Numerous theories have been utilised and developed to explain why people become involved in gangs, including theories of social disorganisation (Lane and Meeker 2004), cultural transmission (Papachristos and Kirk 2006; Shaw and McKay 1931), and differential association (Sutherland and Cressey 1960). More recently, social field theories have been used to explore the motivations and behaviour of gang-involved young people (see Harding 2014: 43-62 for a detailed account of how social field theory can be applied to understand and explain gang-related attitudes and behaviour). In short, social field theories posit that the experiences, views and behaviour of specific actors should be understood in the context of the particular terrains of action that these actors inhabit - their 'social fields' (see Bourdieu and Wacquant 1992; Furstenberg 1969; Hilgers and Mangez 2014; Martin 2003). The primary goal of actors within a particular social field is often to make best use of their skills and resources to achieve advantage over others and bring about their own success whilst striving for distinction (Bourdieu 1990, Harding 2014). It is important to note that each field has its own internal logic, meaning that actors' attitudes, decisions and behaviours are difficult to understand from an outsider's perspective. The significance of respect to gang-involved young people, for example, is a factor that is likely to be underappreciated or misconstrued by those without a good understanding of the gang social field. Each field retains its own bespoke set of rules, alongside an illusio, or set of beliefs held by those within the field, such that it becomes a 'field of organised striving' (Martin 2003: 20).

Harding (2014: 60) develops the concept of social competition and likens the gang social field to a street casino. Inside the casino, the aim of the game is to increase one's street capital, defined as an aggregate of cultural capital (street knowledge and street skills), habitus (internalised socialisation of values, behaviours and demeanours), local history, family connections, networks (social capital), relationships, reputation, status and symbolic capital (available assets of recognition, honour and prestige). An individual's habitus governs their actions in the sense that it can shape what is regarded 
Challenging the orthodoxy on pupil gang involvement: When two social fields collide

as a permissible or credible action within the social field (Fligstein and McAdam 2012). It is worth noting that researchers interested in understanding the phenomenon of youth gangs have developed concepts broadly analogous or related to street capital, such as anti-social capital (Deuchar 2012) and street habitus (Fraser 2013). New entrants to the casino - those who have recently become involved in gangs - typically start with a low quantity of chips (street capital) relative to other players who have been frequenting the casino for longer periods of time. It is important to note, however, that street capital does not increase in a straightforward, linear manner with age and time spent within the casino. Indeed, a gang member's entire reserves of street capital can be wiped out by one poorly placed bet, for example, the loss of a significant quantity of drugs following an attack by a member of a rival gang.

The street casino theoretical framework offered a useful lens for approaching the fieldwork data generated by the current study. The street casino, however, was not the only social field inhabited by gang-involved young people. Upon entering the school gates - and under a particular set of circumstances - it was possible for gang-involved young people to leave the street casino and transition into the social field of the school, which operated with a somewhat different internal logic. One way to understand and explain the impact of gang involvement on pupils' attitudes and behaviour within schools, therefore, is to imagine young people moving between these two social fields. In particular, it is worth considering the shifting goals of gang-involved young people, depending on which social field they perceived themselves to be operating within.

\section{Methodology}

The current study aimed to explore the experiences and views of pupils and members of staff in relation to how gang involvement affects pupils' attitudes and behaviour. It employed a case study design, suitable for exploring these experiences and views in-depth, in a small number of schools (Yin 1993). Fieldwork was conducted in five Alternative Provision schools (AP) across three major cities in the UK in 2015. AP differs from mainstream education in a number of ways. Typically, pupils are referred to AP because of behavioural, emotional, and social difficulties and a general disengagement from their existing education. The young people in AP are more likely to be known to social services and criminal justice agencies, and to be involved with, and affected by, gang involvement and youth violence (Taylor 2012). The most up-to-date, publicly available statistics show that there were 22,032 young people in AP in the UK in 2015, with figures projected to remain stable at this level until 2020 (Department for Education 2016).

The five participating alternative education schools were identified based on a combination of convenience and snowball sampling. Prior to the commencement of the fieldwork, each school indicated to the researchers that a proportion of their pupils were involved with urban street gangs. The schools were located across three major cities in the UK and varied in size, with intakes ranging from around 25 to 50 pupils. The vast majority of pupils in these schools were aged between 14 and 16. All five schools were mixed gender, although every school had a higher proportion of boys on their roll than girls. Periods of participant observation were conducted in each AP, totalling approximately 50 hours. Interviews were conducted with 16 boys and four girls. Of the 20 pupils interviewed, seven were gang-involved (in terms of both self-nomination and teacher identification). Interviews were conducted with both 14 male and 11 female staff. Discussions not only focused on the AP in which the interviews were taking place, but also mainstream schools and pupil referral units, because all of the pupils and many members of staff had recent experience of attending or working in these institutions. Therefore, this paper has relevance across the entire UK educational landscape of mainstream schools, pupil referral units and AP. 
Challenging the orthodoxy on pupil gang involvement: When two social fields collide

Data analysis began following the first period of observation. Interviews were fully transcribed and coded into the software programme, NVivo, shortly after they had been conducted. Coding of the transcripts began after the first interview and observation notes were transcribed and integrated into the analysis alongside interview data. We adopted an approach to the theory-data relationship developed by Layder (1998), adaptive theory, which posits that researchers should make good use of extant theoretical ideas, albeit they should avoid skewing their interpretation of data by forcing it to fit a predefined theoretical framework and associated concepts. In relation to the current study, therefore, theoretical ideas stemming from social field theories were used as a lens through which to approach the interpretation of fieldwork data and concepts that seemed useful in aiding our understanding were utilised; when the data did not seem to 'fit' predefined theoretical frameworks, concepts were refined or discarded, and replaced.

Schools and social field theory

Before discussing the relationships between gang involvement and pupil attitudes and behaviour, it is worth noting the ways in which social field theory and its associated concepts have been applied and developed in the context of education. Ferrare $(2013,2015)$, for example, advanced a version of field theory that attempted to shift the focus away from so-called pupil deficits and towards a consideration of the practices and meanings of different field positions, highlighting the importance of local context in particular. Grenfell (2009: 32), stressing the slippery nature of the terms, has urged researchers to use habitus, field, capital, and social capital not simply as analytical concepts, but as 'epistemological matrices' that can enable researchers to better understand and explain the fundamental process of knowledge formation. And Reay (2015: 13-15), drawing on a case study with a 'hard-working, wellbehaved, poor, white, working-class boy', highlighted the 'divided habitus', internal conflict and psychic costs that were generated through a pupil's struggle to navigate between two different but equally compelling social fields: that of the classroom, characterised by the pursuit of academic success, and that of working-class masculinities, characterised by a sense of solidarity with the pupil's working-class peer group and a generalised rejection of the value of education.

In contrast to these papers, which primarily explore the internal dynamics of particular social fields, the primary focus of this paper concerns the distinction between the 'school social field' - defined as the field inhabited by pupils during school hours - and the 'gang social field' (or 'street casino') inhabited by gang-involved pupils outside the school gates. Unlike the bright lights and glamour of the street casino, the school social field was perceived to be relatively unexciting and mundane by the vast majority of young people who participated in this study. In same the way as winning in the street casino involved increasing one's street capital, winning in the school social field involved increasing one's school capital. It is worth noting, however, that compared to the high value placed on the street casino's pay-out of street capital, the school's pay-out was typically rather less coveted. Therefore, whilst all gang-involved young people playing in the street casino were keen to increase their chips at a rapid rate, their enthusiasm to 'win' in the school social field was often more limited.

Increasing one's school capital constituted different things to different pupils, and therefore the meaning of school capital was relatively nebulous and fluid compared to street capital. Some young people regarded 'winning' to mean gaining a good set of GCSE test results, whereas for others, GCSEs were a distant concern. For some, winning simply meant recording their attendance for a full school day without the need for the school to contact their parent(s) or guardian(s); for others, winning meant getting themselves into trouble in order to receive adult attention - something that many young people in AP crave (Taylor 2012). For some pupils, winning meant gaining and maintaining the respect of their fellow peers in the school. Crucially, however, this respect was not 
Challenging the orthodoxy on pupil gang involvement: When two social fields collide

dependent on the same attitudes and behaviours that they were required to demonstrate in the street casino. As one teacher was eager to point out, their school took concerted action to keep street casino rules out of the school environment:

Darius: The minute we hear anything about post-codes or them reppin' a particular area, 'Where you from?', this, that or the other, we stamp it out. We show them that those things don't apply when they enter our school - they won't get respect from us or other students by behaving like that in here.

A note on terminology

One final issue is worth addressing before we proceed to discuss the paper's substantive findings: the definition of the terms 'gang' and 'gang involvement'. This is a thorny subject, particularly in the UK. Some researchers have argued that youth gang 'problems' are hyped up by professionals and 'gang talkers' with vested interests in exaggerating the nature and scale of youth gangs (Hallsworth and Young 2008; Smithson and Ralphs 2016). Others, however, have highlighted the serious levels of violence committed by people involved in street gangs and the negative effects that gang involvement has on outcomes for young people (Densley 2013; Harding 2014; Pitts 2012). The way in which 'gangs' and 'gang involvement' are defined, therefore, is not a trivial nor inconsequential matter.

The approach taken in the current paper was to allow the terms 'gangs' and 'gang involvement' to be defined by the study's participants. In contrast to the findings of some previous studies in the UK that revealed young people railing against the 'gang label', (see Joseph and Gunter 2011; Hallsworth and Young 2008), the young people involved in the current study (as well as teachers and other professionals) had no qualms about discussing gangs or gang involvement, and did not express the belief that this was a label created by adult professionals, imposed on young people who were not involved in gangs. It is unclear whether this is a product of the particular locations in which the current research took place, or the result of shifts in attitudes, norms, or language over time, or indeed some other combination of factors. Whilst the authors of this paper did not explicitly probe young people's or professionals' definitions, it seemed apparent from our discussions that gangs constituted groups of young people affiliated with a particular area and involved in some form of illegal activity (such as violence or drug dealing) on a regular basis.

The following sections explore the relationships between pupil gang involvement and violence in schools, the possession and use of weapons, and young people's attachment to their school and engagement in their education.

\section{Gang-involved pupils and violence}

Previous studies have linked gang involvement to an increase in violent behaviour (O'Brien et al. 2013). The term 'violence' in this section refers to both verbal and physical conflict between different pupils, and between pupils and teachers. Based on the extant literature, it would reasonable to assume that the presence of gang-involved pupils is likely to enhance the amount of violence in schools. Indeed, violence has been identified as a primary means of increasing one's street capital inside the gang social field (Harding 2014). Reflecting on the five case studies involved in the current research, however, the reality seemed less straightforward. Whilst all of the participating schools had issues around pupil gang involvement, many members of staff and pupils reported that the vast majority of violent incidents inside their schools were not gang-related. According to teachers as well as pupils, these schools experienced a certain level of verbal and physical conflict because a high proportion of the pupils in attendance had histories of violent behaviour, which in many cases had triggered their 
Challenging the orthodoxy on pupil gang involvement: When two social fields collide

exclusion from mainstream settings (Taylor 2012). In fact, some members of staff argued that ganginvolved pupils displayed a lower propensity for violence inside school premises, compared to their peers who were not involved in gangs:

Kelly: Because the students that are gang-involved seem to have more of a culture of respect around them, possibly that might be a reason for them not being involved in fights and stuff, because the [non-gang-involved] students don't tend to really bother them too much; but then [the gang-involved students] don't seem to particularly bother the other students either.

This finding makes sense when considered through a lens of social field theory. Whilst violence was an important resource for gang-involved young people in terms of increasing their street capital inside the gang social field, it was less useful inside the school social field where violence was likely to decrease a pupil's capital owing to an internal logic that devalued violent behaviour. This was particularly the case when gang-involved pupils had established strong attachments to their school and fellow pupils:

Josh: This school is like, all together. We're like a family here, we stick up for each other; we're like, friends. But that school [a previous Pupil Referral Unit from which Josh was expelled] is like, split up, it's like being in America.

Josh recounted his experience at a previous school in which fights between young people involved with rival gangs were common, a situation he likened to 'being in America'. In his current school, however, despite the presence of rival gang-involved young people, teachers had worked hard to keep the internal logic of the gang social field outside of the school gates. Indeed, one teacher in Josh's school spoke about the school's efforts to instil an ethos of all pupils and staff members in the school being part of the same 'gang' - a school family.

Another participating school had two pupils on its roll who had been involved in gangs for over three years. Whilst these pupils were physically well-built compared to other pupils, the relative maturity of their character also commanded a certain level of respect from their peers. These two gang-involved young people contributed to the creation of a degree of order and calmness in the classroom that some staff members believed would not have existed without their presence. Greg, a member of staff, suggested that gang-involved pupils were typically more mature than non-ganginvolved pupils, which was perhaps because surviving and thriving in a gang social field, particularly for young people in their early teenage years, requires a process of rapid maturation. Data from the fieldwork observations supported this assertion, with many of the gang-involved young people exhibiting relatively calm and composed behaviour compared to other non-gang-involved pupils. Indeed, some teachers were surprised to discover which of their pupils were involved in gangs:

John: The first year I was in this school, one of the leaders of a big gang in [City X] was my student. Back then I didn't know that. He was good for helping me keep the class quiet . . . I never knew he was in a gang until he left the school.

Being within school premises appeared to offer gang-involved pupils respite from the potentially volatile and violent encounters that they frequently negotiated in the gang social field. As one staff member put it:

Mike: I think that's one of the reasons why [gang-involved young people] like coming here, because they don't have the responsibilities that they have outside in the community. They 
Challenging the orthodoxy on pupil gang involvement: When two social fields collide

come here and they are just school kids, just themselves, you know, not having to deal with the stuff they have to outside.

This view was corroborated by gang-involved pupils during interviews and informal discussions. The major safety concern of one gang-involved pupil was that he sometimes could not get into school when he arrived, leaving him exposed to potential danger, presumably from rival gang members, whilst standing outside the school entrance:

Interviewer: The last bit is whether you think there is anything the school could do to help you feel safer?

James: Leave the door open, because if you come and it is locked and we don't have the code, we can be out there for hours and it isn't safe with other people around.

Although the presence of rival gang members within the same school posed significant challenges, the success of some schools in creating a social field in which capital was not enhanced by violent behaviour, and within which pupils from rival gangs could 'rub along' together during school hours, was impressive:

Liane: Last year we had another student, Ethan, very much involved in all that [gang culture], you know, quite high up in the pecking order of things. He comes to school absolutely fine, and he would be in the same class as Darren [member of a rival gang], absolutely fine - no concerns. As soon as school ended, Darren said, 'If Ethan sees me on the street, he'll cut me up', and Ethan would tell you, 'Yeah, I would'. But we've got to that point where in school we have control of it.

Despite the success of some of the APs in the current study in terms of minimising gang-related violence, however, most pupils reported that the presence of rival gang members within mainstream schools and pupil referral units, many of which they had attended in the past, produced a tense atmosphere, punctured by frequent outbreaks of violence:

Luke: At my last school there was bare gangs; it was a violent place. There were fights everyday...police was always in.

Josh: That school has always got problems with gangs. I went there for a week, but I didn't like it. I had a fight with [a pupil] because he was trying to steal my money, so I beat him up and he ended up in hospital.

Josh was transferred away from the school in question following this incident. The situation he found himself in provided a good example of the pressure that pupils faced to affiliate with gangs when they attended schools with a gang presence. In other words, when the gang social field infiltrated, overlapped, or dominated the school social field, the negative impact that gang-involved young people could have on other pupils in the school was significant. Josh, a young person who resisted gang involvement, was consequently victimised by other pupils who attempted to steal his money because of his isolated social status. Attacking other pupils was often seen as an easy and dependable route to acquiring additional street capital, useful for further advancing one's position in the street casino (Harding 2014).

Most members of staff had concerns around gang-involved pupils carrying weapons. 
Challenging the orthodoxy on pupil gang involvement: When two social fields collide

Although research indicates that knife possession increases the likelihood of a young person being victimised (see McVie 2010; Peterson et al. 2004; Taylor et al. 2007), members of staff typically reported that the reason underpinning a young person's decision to carry a knife was to feel safer. Gang-involved young people in particular carried knives to protect themselves when travelling to and from school, often through areas associated with rival gangs:

Chris: Some of my pupils carry knives because they're repping this so-called post-code rubbish, so for them to go from one postcode to another they can't walk freely - they carry a knife for protection because they are scared.

Despite the majority of members of staff believing that some gang-involved pupils carried weapons within their schools, most did not seem worried about their own personal safety. Primarily, this was because they believed their pupils carried weapons to feel safe whilst on their journeys between home and school. During these journeys, young people might be required to pass through unfamiliar areas, including rival gang areas, leaving them vulnerable to attacks from other young people. Most members of staff did not think that pupils carried weapons for use within the school:

Scott: They would never use them in school, that isn't why they're carrying. Most of them don't bring them inside anyway; they stash them somewhere nearby and collect them on their way home.

This constitutes an archetypal example of the transition made by young people between two very different social fields. In the volatile gang social field, where violent conflict was a key part of street capital, young people carried knives because they believed this was necessary for their own protection. Young people recognised, however, that violent conflict did not take on the same meaning inside the school social field. If schools could create an environment in which school capital did not depend on violence against other pupils, then as Scott pointed out during our interview, pupils would be more inclined to leave knives outside the school premises.

The fact that the school social field shut down every weekday afternoon meant that ganginvolved pupils were ejected back into the street casino on their journeys home from school - a time when there was a particularly high risk of gang-related violence occurring (Irwin-Rogers 2016). One member of staff recounted an instance in which one of her students had been recognised in a music video that had been uploaded to the internet and subsequently targeted by young people from a rival gang:

Liane: Last year [Gang X] was doing a music video dissing [Gang Y], and Daniel [a member of Gang X] was seen in the back of that video; he wasn't actually saying anything, he was just seen on that clip.

Several young people in the rival gang that had been denigrated in the music video had recognised Daniel and targeted him in a revenge knife attack on his way home from school:

Liane: Daniel had gone home and said nothing to his mum about being stabbed, so I had rung in the morning and said to his mum, 'Is Daniel ok?...Can you just go and have a check on him?'... he had been stabbed in about six places near the top of his thigh.

To avoid attention from the police and the risk of him being labelled a snitch, Daniel had initially decided not to get his stab wounds treated in hospital; he only agreed to treatment after a member of 
Challenging the orthodoxy on pupil gang involvement: When two social fields collide

school staff personally intervened and offered to escort him to hospital.

Another member of staff explained that even though pupils from rival gangs could 'rub along' with each other for the most part, there were times when conflict would spill into school from incidents occurring between pupils outside of school hours:

Chris: They [pupils involved in rival gangs] genuinely do play together - they play football together, they eat dinner together, they're fine...walking back to the bus stop they're still fine. They may be fine for the whole weekend, but sometimes what happens is that when they get back to their own postcodes, one of their other friends then says, 'Oh, were you talking to soand-so from [Area B] today?', 'Na, I don't like him', and then they'll pop up on social media and start disrespecting each other in a rap video, then they'll come back to school on Monday and start kicking off.

Trouble between young people in the gang social field, therefore, had the potential to transfer over into the social field of the school. Overall, however, pupil gang involvement was not straightforwardly linked to an increase in violence within schools as one might assume from the existing gangs literature (Ang et al. 2015; Forber-Pratt et al. 2014). In particular, violence concerning gang-involved pupils could be contained and reduced if the internal logic of the gang social field could be kept outside of the school gates.

\section{Gang-involved pupils and educational engagement}

As with violence, the connection between educational engagement and gang involvement was not straightforward. Based on previous research, it might reasonably be assumed that gang-involved pupils would be less engaged in their education compared to their non-gang-involved peers (Pyrooz 2014; Yiu and Gottfredson 2013). A number of staff members, however, were keen to challenge this assumption:

Interviewer: The students who are in gangs, would they cause more problems in school than other students, or not?

Mark: I would have thought, yes; instantly, I would think yes. But the three that I know who are in gangs are probably three of the most well-behaved. But then, how we interpret that is that they already have that reputation, they don't need to show it off.

Kelly: The two students that are gang involved here, they have fairly good academic ability, so they are perfectly fine to just sit down and get on with their work. They could be sat in the classroom for an hour just writing, whereas for some of the other students that is just not where they are at.

Participation and success in the gang social field endowed gang-involved young people with a certain standing among their school peers. Not only did pupils treat gang-involved young people with a degree of respect that was not automatically afforded to other pupils, but gang-involved young people themselves exhibited high levels of social confidence within school (see further Parkes and Conolly 2013). In short, as is reflected by the following observation note, gang-involved pupils generally seemed relatively secure about their status inside APs because of their reputation in the gang social field outside school. They therefore did not feel the need to prove themselves through altercations with other pupils: 
Challenging the orthodoxy on pupil gang involvement: When two social fields collide

\begin{abstract}
Two pupils got into an argument before lessons this morning. Sean was winding up Emma, and got a reaction when he made fun of what she was wearing. Emma pushed Sean and then refused to attend her English lesson. About ten pupils got involved in the argument; mostly verbal abuse, but some physical confrontation. At one point, Kieran [a gang-involved pupil in the AP] said something like, 'It's calm, you lot are like babies'. Most of the time, Kieran and James [another gang-involved pupil] sat in the corner chatting, and ignored what was going on.
\end{abstract}

\title{
Observation
}

note

Not only did members of staff commonly report that gang-involved pupils were better behaved than other pupils, but some also reported that the presence of gang-involved students could encourage an environment in which other pupils were better behaved and focused on their work:

John: One of the leaders of a big gang in [City X] was my student ... he was good for helping me keeping the class quiet, everyone did their work.

An incident during a period of observation indicated the potentially positive impact on school climate that a gang-involved young person could have. Simon, a teacher who was shortly due to be taking a two-month leave of absence from the school, was concerned about the potential for pupils' behaviour and work-ethic to deteriorate whilst he was away. He decided to speak to Marcus, a gang-involved pupil, who was acknowledged by all members of staff to be particularly influential amongst other pupils - influence that stemmed in large part from his position in a well-known local street gang. Simon spoke to Marcus about how important the next few months would be for many pupils who were approaching their GCSE examinations. He acknowledged the power that Marcus had in terms of influencing the behaviour of other pupils in the school, an issue that I sensed had been discussed on several previous occasions. Simon stressed to Marcus the importance of Marcus using his influence to foster a positive attitude among pupils toward school and learning in the remaining few months before final year examinations. Marcus responded maturely and agreed to try his best to ensure other students remained focused on their exams, thereby helping to further embed and reinforce the prosocial, pro-learning internal logic of the school social field.

It is worth noting that despite being involved in a gang outside school, Marcus had relatively high educational aspirations. He reported during his interview that his goal was to study business at university. Indeed, on the whole, gang-involved pupils exhibited higher levels of ambition and drive compared with their non-gang-involved peers in AP. Whilst much of this ambition and drive was currently being directed toward success in urban street gangs - particularly in terms of making money from drug dealing - most gang-involved young people also expressed a desire to earn money legitimately:

Liam: It's better for me to do my grades, go to uni, and if it works out have a legit business, work a legit life, because then I know I'm not looking behind my back. I'm not driving and thinking someone is going to pop this door and put two in my head because what I'm doing is illegal. 
Challenging the orthodoxy on pupil gang involvement: When two social fields collide

This positive account of the relationship between gang involvement and engagement in education, however, did not apply to all gang-involved young people. Many members of staff believed that a gang lifestyle could leave gang-involved pupils feeling demotivated:

Amy: A lot of them are so demotivated to learn, because they think, 'Why should I go to college when I can get so much money on the streets?'

Gang involvement, drug dealing, and the allure of fast money appeared to offer some pupils an attractive alternative to what they perceived to be the difficult grind of education that ultimately held little prospect of success. Although Liam expressed a strong desire to leave the gang social field, his vision of the future was torn because of the perceived difficulty of succeeding in alternative social fields:

Liam: The way that teachers make it out is that you go college, you go uni, and then the minute you step out of uni there's a guy in a suit that says, 'Yo, I've got a job for you in a big company'. Ain't happening like that 'cause there's a million people that want that same job what have you got that they haven't? You know what I'm saying?

Some gang-involved young people had become so demotivated that they had stopped attending school entirely. In these cases, schools attempted to engage students using outreach work, a process by which members of staff would visit the pupil in a location outside of school, such as their home or a local library, to provide them with mentoring and support with their learning. Members of staff generally reported that a higher proportion of gang-involved young people were educated in this way compared to their non-gang-involved peers.

There was also some evidence that incidents related to gang-involvement that occurred outside school hours, such as violent conflict between rival gang members, could spill into school and significantly affect pupils' ability to concentrate on their work:

Sam: He [a gang-involved pupil] is always telling me about what's going down on the street for him. One day he said, 'Yeah, my mate got stabbed yesterday. There was a group of boys; they stabbed my friend'. And it messed him up for the whole day in school because that is all he kept thinking about, you know what I mean, he didn't want to study, he was just thinking about revenge.

This finding resonates with previous research in the UK that found that pupils were easily distracted from their work by discussion of gang-related incidents occurring outside the school gates (Broadhurst et al. 2009). The hype and hysteria surrounding events occurring in the community-based gang social field, therefore, could not always be kept outside of the school gates.

In summary, the relationship between gang involvement and young people's engagement in education varied depending on individual circumstances. Some gang-involved young people showed signs of relative maturity compared to their non-gang-involved peers, often precisely because of the rapid maturation process that life inside the gang social field could entail. These pupils behaved relatively well and made relatively good progress in terms of their education. On the other hand, certain aspects of a gang lifestyle had the potential to demotivate others from engagement in their education, leading them to believe that the quick money associated with drug dealing and gang involvement offered them a more attractive future than the pursuit of legitimate careers.

\section{Discussion}


Challenging the orthodoxy on pupil gang involvement: When two social fields collide

The evidence from the current study indicates that the relationships between gang involvement, violence and pupils' engagement in their education are not straightforward. Instead, gang involvement exerts a nuanced influence on young people's attitudes and behaviours, which depends in large part on the particular circumstances surrounding individual pupils. A useful way of understanding and explaining these nuances is to consider the transition made by gang-involved young people between two very different social fields: that of the school and that of the gang.

We found that when schools had been successful in creating a clearly defined social field, characterised by a pro-social, pro-education internal logic, this could serve to displace the gang social field, along with its anti-social, anti-education internal logic that dominated pupils' lives outside the school gates. Some of the schools achieved this by instilling an ethos of a whole-school gang, in which all pupils agreed to put aside their differences whilst in school, regardless of their gang involvement outside. Pupils reported that when the presence of rival gangs within a school was not effectively addressed, this resulted in frequent outbreaks of violence, as the rules and rewards of the gang social field infiltrated that of the school. Gang-involved young people were far more likely to carry weapons outside school compared to their non-gang-involved peers. Nevertheless, the more that the school environment was perceived by gang-involved young people to be safe, the less likely they were to bring weapons into school. The physical necessity of leaving the school social field at the end of the school day and being ejected back into the street, however, meant many young people would stash weapons outside school premises for protection on their journeys home.

The relationships between gang involvement, school attachment, and academic engagement, were not straightforward. Some teachers were keen to highlight that gang-involved pupils were betterbehaved, more committed to their education and more academically able compared to their non-ganginvolved peers. Other members of staff, however, argued that gang involvement could negatively affect a young person's motivation to attend school and make progress in their learning, as the allure of the street casino and the quick financial rewards of drug dealing could not be matched by the school's offer of education. On the whole, it seems that it is not gang involvement in and of itself that leads young people to disengage from school and exhibit disruptive, violent behaviour on school premises. Instead, the potential problems of educating gang-involved pupils surface only when the rules and rewards of the gang social field infiltrate that of the school.

Whilst this paper indicates that it is possible to educate gang-involved young people in a safe and nurturing environment, it is worth noting the limitations of both the study itself and its potential implications for policy and practice. First, the particular lens that we have developed and applied in this paper entailed some degree of reductionism. For example, we neglected to explore some of the potential distinctions that may have existed within the school and gang social fields (see, for example, Reay 2015), in favour of focusing our attention on the distinctions and tensions between these fields. Furthermore, it is important to highlight that as the research was based on a case study approach with a relatively small sample size, it arguably generated what some have termed an 'exemplary' (as opposed to a 'generalisable') form of knowledge (see Thomas 2011). Whilst there was a high degree of consistency in relation to the data collected across the five schools (located in three different cities), judgements regarding the extent to which, and the ways in which, the findings might be generalisable and applicable to schools outside the study's immediate sampling frame are best made by professionals working in those schools.

Although it is beyond the purview of this paper to provide an in-depth exploration of the ways in participating AP sought to establish a school social field that displaced that of the gang, a couple of points are worth noting. First, the creation and maintenance of supportive and trusting relationships between staff and gang-involved pupils appeared to be paramount. In this regard, compared to mainstream schools, the APs involved in the current study benefitted from relatively high staff-to- 
Challenging the orthodoxy on pupil gang involvement: When two social fields collide

student ratios and alongside classroom teachers often employed mentors with high levels of cultural capital. In short, this resulted in pupils reporting better relationships with adults in AP compared to pupil referral units or mainstream schools. These relationships helped pupils to feel safe within the AP, and better enabled adults to displace the internal logic of the gang social field with the alternative logic of a school social field that was pro-social and pro-education. Second, APs were able to implement a relatively flexible curriculum, providing teachers with the space to identify and utilise educational hooks, such as music or sport, to reengage pupils in their education (see further IrwinRogers 2016).

The extent to which mainstream schools are able to replicate these tactics is of course strictly limited by top-down curriculum priorities and restraints, as well as severe restrictions on resources. The implications of the findings discussed in this paper may, therefore, have more relevance to those working in educational policy, rather than professionals working in particular schools. In any case, the primary aim of this paper has not been to lay out a blueprint for educational policy or practice, but to illustrate the implications of gang involvement for pupil attitudes and behaviour, and more specifically to challenge the orthodoxy on this issue presented in the literature to-date.

\section{Conclusion}

Educating gang-involved young people who have been excluded from mainstream schools is not an easy task. Nevertheless, as discussed above, it may be possible for schools to build on the strengths of gang-involved young people, such as the positive character traits that many exhibit. The ganginvolved pupils involved in the current study were relatively confident, driven and capable, compared to their non-gang-involved peers in AP. At the time of the research, their energies outside school were directed toward negative activities, such as drug dealing and violent conflict with other young people involved in rival gangs. Many of these young people, however, expressed a desire to lead 'legit' lives away from the risks and stresses that characterised the gang social field.

Whist the literature on schools and gangs presents an invariably negative portrait of the effects of gang involvement on pupil attitudes and behaviour (see Ang et al. 2015; Yiu and Gottfredson 2014), the findings presented in the current paper challenge this orthodoxy, or at least, subject it to certain caveats. By adopting a lens of social field theory, we found that the effects of gang involvement on pupils' attitudes and behaviour are nuanced and largely dependent on the success with which schools managed to create and sustain pro-social, pro-education school social fields that could serve to displace (albeit temporarily) the gang social fields that dominated pupils' lives outside the school gates. Displacing the internal logic of the gang social field with an alternative that values education and spurns violence is not an easy challenge. It is, however, a challenge that some schools in the current study had embraced and overcome.

We would like to conclude by noting that gang-involved young people do not typically spend their entire waking hours wedded to a 'gang member' identity (Garot 2010). Gang-related attitudes and behaviours are exhibited only under certain conditions and around certain people; in other words, within a gang-related social field. We found that if gang-involved young people are given the opportunity to leave the street casino - with all its associated pressures and risks - and transition into a school social field with a different internal logic, they will often embrace it. When this happens, the negative effects associated with the presence of rival gangs within a school fade, and gang-involved young people simply become young people in need of a decent education.

\section{REFERENCES}


Challenging the orthodoxy on pupil gang involvement: When two social fields collide

Ang, R. P., Huan, V. S., Chan, W. T. Cheon, S. A. and Leaw, J. N. (2015) The role of delinquency, proactive aggression, psychopathy and behavioural school engagement in reported youth gang membership. Journal of Adolescence. (41), 148-156.

Bourdieu, P. (1990) The Logic of Practice (Cambridge, Polity Press).

Bourdieu, P. and Wacquant, L. J. D. (1992) An invitation to reflexive sociology (Chicago, University of Chicago Press).

Bradshaw, C. P., Waasdorp, T. E., Goldweber, A. and Johnson, S. L. (2013) Bullies, Gangs, Drugs, and School: Understanding the Overlap and the Role of Ethnicity and Urbanicity. Journal of Youth Adolescence. 42, 220-234.

Broadhurst, K., Duffin, M., Taylor, E. and Burrell, A. (2009) Gangs and schools: A report for the NASUWT (London, NASUWT).

Craig, W. M., Vitaro, F., Gagnon, C. and Tremblay, R. E. (2002) The road to gang membership: Characteristics of male gang and non-gang members from ages 10 to 14. Social Development. 11, 5368.

Densley, J. A. (2013) How Gangs Work: An Ethnography of Youth Violence (Palgrave, London).

Department for Education (2016) Schools, pupils and their characteristics, January 2016. Statistical Release (London, Department for Education).

Deuchar, R. (2012) The impact of curfews and electronic monitoring on the social strains, support and capital experienced by youth gangs members and offenders in the west of Scotland. Criminology \& Criminal Justice. 12(2), 113-128.

Esbensen, F. -A., Huizinga, D. and Weiher, A. W. (1993) Gang and non-gang youth: Differences in explanatory factors. Journal of Contemporary Criminal Justice. 9, 94-116.

Ferrare, J. J. and Apple, M. W. (2015) Field theory and educational practice: Bourdieu and the pedagogic qualities of local field positions in educational contexts. Cambridge Journal of Education. 45(1), 43-59.

Ferrare, J. J. (2013) The duality of courses and students: A field-theoretic analysis of secondary school course-taking. Sociology of Education. 86, 139-157.

Fligstein, N. and McAdam, D. (2012) A theory of fields (Oxford, Oxford University Press)

Forber-Pratt, A. J., Aragon, S. R. and Espelage, D. L. (2014) The Influence of Gang Presence on Victimisation in One Middle School Environment. Psychology of Violence (4)1, 8-20.

Fraser, A. (2013) Street habitus: gangs, territorialism and social change in Glasgow. Journal of Youth Studies. 16(8), 970-985.

Furstenberg, F. (1969) Der Aufteigsproblem in der modernen Gesellschaft (Stuttgart, Ferdinand Enke Verlag). 
Challenging the orthodoxy on pupil gang involvement: When two social fields collide

Garot, R. (2010) Who You Claim: Performing Gang Identity in School and on the Streets (New York, New York University Press).

Gormally, S. (2015) 'I've been there, done that...': A study of youth gang desistance. Youth Justice. $15(2), 148-165$.

Gottfredson, G. D. (2013) What can schools do to help prevent gang-joining?, In: T. R. Simon, N. M. Ritter and R. R. Mahendra (Eds) Changing course: Preventing gang membership (Washington, DC, U.S. Department of Justice, U.S. Department of Health and Human Services).

Grenfell, M. (2009) Applying Bourdieu's field theory: the case of social capital and education. Education, Knowledge, \& Economy. 3(1), 17-34.

Hallsworth, S. and Young, T. (2008) Gang talk and gang talkers: A critique. Crime, Media, Culture. 4(2), 175-195.

Harding, S. (2014) The Street Casino: Survival in Violent Street Gangs (Bristol, Policy Press).

Hawkins, J. D., Herrenkohl, T. I., Farrington, D. P., Brewer, D., Catalano, R. F., Harachi, T. W. and Cothern, L. (2000) Predictors of youth violence. Office of Juvenile Justice and Delinquency Prevention Juvenile Justice Bulletin, April 2000.

Higginson, A., Benier, K., Shenderovich, Y., Bedford, L., Mazerolle, L. and Murray, J. (2014) Protocol: Predictors of youth gang membership in low- and middle-income countries: A systematic review (The Campbell Collaboration).

Hilgers, M. and Mangez, E. (2014) 'Introduction to Pierre Bourdieu's Theory of Social Fields', In M. Hilgers and E. Mangez (Eds), Bourdieu's Theory of Social Fields: Concepts and applications (Routledge, Oxford).

Home Office (2016) Ending Gang Violence and Exploitation (London, HMSO).

Irwin-Rogers, K. (2016) Safer Schools: Keeping gang culture outside the gates (London, Catch22).

Joseph, I. and Gunter, A. (2011) Gangs Revisited: What's a gang and what's race got to do with it? (London, Runnymede).

Krohn, M. D., Ward, J. T., Thornberry, T. P., Lizotte, A. J. and Chu, R. (2011) The cascading effects of adolescent gang involvement across the life course. Criminology. 49, 991-1028.

Lane, J., \& Meeker, J. W. (2004) Social disorganization perceptions, fear of gang crime, and behavioral precautions among Whites, Latinos, and Vietnamese. Journal of Criminal Justice. 32, 4962 .

Lenzi, M., Sharkey, J., Vieno, A., Mayworm, A., Dougherty, D. and Nylund-Gibson, K. (2014) Adolescent Gang Involvement: the role of individual, family, peer and school factors in a multilevel perspective. Aggressive Behavior. 41(4), 1-12. 
Challenging the orthodoxy on pupil gang involvement: When two social fields collide

Martin, J. (2003) What is field theory. American Journal of Sociology. 109 (1), 1-49.

McVie, S. (2010) Gang Membership and Knife Carrying: Findings from the Edinburgh Study of Youth Transitions and Crime (Edinburgh, The Scottish Centre for Crime and Justice Research).

Melde, C. and Esbensen, F. -A. (2011) Gang Membership as a Turning Point in the Life Course. Criminology. 49, 513-552.

Ministry of Justice (2011) Statistical bulletin on the public disorder of 6th to 9th August 2011 October update (London, HMSO).

MOPAC (2016) MOPAC Challenge: Gangs. Available at: www.london.gov.uk (accessed 15 January 2018).

Ozer, M. M. and Engel, R. S. (2012) Revisiting the use of propensity score matching to understand the relationship between gang membership and violent victimisation: A cautionary note. Justice Quarterly. 29, 105-124.

O'Brien, K., Daffern, M., Chu, C. M. and Thomas, S. D. M. (2013) Youth gang affiliation, violence, and criminal activities: A review of motivational, risk, and protective factors. Aggression and Violent Behaviour. 18, 417-425.

Papachristos, A. V. and Kirk, D. S. (2006) Neighbourhood effects on street gang behaviour. In J. F. Short and L. A. Hughes (Eds) Studying youth gangs (Oxford, Altamira Press).

Parkes, J. and Conolly, A. (2013) Dangerous encounters? Boys' peer dynamics and neighbourhood risk. Discourse: Studies in the Cultural Politics of Education. 34(1): 94-106.

Peterson, D., Taylor, T. J. and Esbensen, F. -A. (2004) Gang membership and violent victimisation. Justice Quarterly. 21, 793-815.

Pitts, J. (2012) Reluctant Criminologists: criminology, ideology and the violent youth gang. Youth and Policy. 109, 27-45.

Pyrooz, D. C. (2014) From Colors and Guns to Caps and Gowns? The Effects of Gang Membership on Educational Attainment. Journal of Research in Crime and Delinquency, 51(1), 56-87.

Pyrooz, D. C. and Decker, S. H. (2011) Motives and methods for leaving the gang: Understanding the process of gang desistance. Journal of Criminal Justice. 39(5), 417-425.

Reay, D. (2015) Habitus and the psychosocial: Bourdieu with feelings. Cambridge Journal of Education. 45(1), 9-23.

Sharkey, J. D., Shekhtmeyster, Z., Chavez-Lopez, L., Norris, E. and Sass, L. (2011) The protective influence of gangs: Can schools compensate? Aggression and Violent Behaviour. 16, 45-54.

Shaw, C. R. and McKay, H. D. (1931) Social factors in Juvenile delinquency. 2:13 (Washington DC, Government Printing Office). 
Challenging the orthodoxy on pupil gang involvement: When two social fields collide

Smithson, H. and Ralphs, R. (2016) Youth in the UK: 99 problems but the gang ain't one? Safer Communities. 15(1), 11-23.

Sutherland, E. H. and Cressey, D. R. (1960) A theory of differential association. Principles of criminology. $6^{\text {th }}$ Edition (Chicago, Lippincott).

Taylor, C. (2012) Improving Alternative Provision. (London, Department for Education).

Taylor, T. J., Peterson, D., Esbensen, F. -A. and Freng, A. (2007) Gang membership as a risk factor for adolescent violent victimisation. Journal of Research in Crime and Delinquency. 44, 351-380.

Thomas, G. (2011) The case: generalisation, theory and phronesis in case study. Oxford Review of Education. 37(1), 21-35.

Thornberry, T. P., Krohn, M. D., Lizotte, A. J., Smith, C. A. and Tobin, K. (2003) Gangs and Delinquency in Developmental Perspective (New York, Cambridge University Press).

Weerman, F. M., Lovegrove, P. J. and Thornberry, T. (2015) Gang membership transitions and its consequences: Exploring changes related to joining and leaving gangs in two countries. European Journal of Criminology. 12(1), 70-91.

Yin, R. K. (1993) Applications of Case Study Research. Applied Social Research Methods Series, 34 (Newbury Park, Sage).

Yiu, H. L. and Gottfredson, G. D. (2013) Gang Participation. Crime and Delinquency. 60, 619-642. 